\title{
Detection of Rubella Antibodies in Human Serum by the Indirect Fluorescent Antibody Technique ${ }^{* *}$
}

\author{
$\mathrm{By}$
}

Gordon C. Brown, H. F. Maassab, J. A. Veronelli, and Th. Franeis Jr.*

With 2 Figures

The demonstration and titration of antibodies for rubella virus has been dependent upon the neutralization technique in tissue culture which relies either upon the interference of the rubella agent with another virus, ECHO 11 (1), or the inhibition of specific cytopathogenic activity in primary human amnion tissue (2). These slow and cumbersome procedures are in large part responsible for the limited progress in the laboratory diagnosis of this disease and on the evaluation of experimental vaccines. Attempts to demonstrate rubella virus by the direct method of immunofluorescence have been unsuccessful to date, probably because of the difficulty in obtaining specific antiserum in sufficiently high titer to conjugate with fluorescein. Unsuccessful attempts to employ the indirect method have also been reported (3). However, since the indirect method has proved satisfactory with certain other agents including the enteroviruses (4) and with measles (5) and since an unusually reliable source of antigen was available, this procedure was attempted. The development of a rapid and specific test for rubella antibodies using the indirect method of fluorescent microscopy with acute and convalescent human sera is herein described.

Acute and convalescent sera had been collected at the University of Michigan Student Health Service through the cooperation of the Director, Dr. Morley Beckett. Fluorescein-labelled goat anti-human gamma globulin

* Virus Laboratory, Department of Epidemiology, School of Public Health, University of Michigan, Ann Arbor, Michigan, U.S.A.

** This investigation was supported in part by Public Health Service Grant No. AI 05876 from The National Institute of Allergy and Infectious Diseases, National Institutes of Health, and in part under the auspices of the Commission on Influenza, Armed Forces Epidemiological Board, and by the Office of the Surgeon General, U.S. Army, Washington, D. C. 
was obtained commercially* and further purified by fractionation on a DEAE column (6). After equilibration with $0.0175 \mathrm{M}$ phosphate buffer at $\mathrm{pH}=6.3$ the DEAE was packed into glass columns under air pressure. Fifteen $\mathrm{ml}$ of undiluted, conjugated serum were placed in the column which was $1 \mathrm{~cm}$ in diameter and $20 \mathrm{~cm}$ in height and eluted with sodium phosphate buffer with stepwise increasing concentrations of $\mathrm{NaCl}$. The fraction eluted at $0.125 \mathrm{M} \mathrm{NaCl}$ in $0.0175 \mathrm{M}$ sodium-phosphate buffer contained the bulk of the labelled specific globulin. A 1:16 dilution of

Table 1. Fluorescent antibody titers of human sera with rubella infected and normal cells

\begin{tabular}{c|c|c}
\hline Serum & Infected cells & Normal cells \\
\hline (Clinical disease) & $1: 2$ & Negative \\
(1) Acute & $1: 16$ & Negative \\
Convalescent & Negative & Negative \\
(2) Acute & $1: 16$ & Negative \\
Convalescent & Negative & Negative \\
(3) Acute & $1: 16$ & Negative \\
Convalescent & Negative & Negative \\
(4) Acute & $1: 16$ & Negative \\
Convalescent & Negative & Negative \\
(5) Acute & $>1: 16$ & Negative \\
Convalescent & $>1: 16$ & Negative \\
(6) Convalescent & $>1: 32$ & Negative \\
(7) Convalescent & & \\
(Subclinical) & $1: 8$ & Negative \\
(8) Post-exposure & $>1: 8$ & Negative \\
(9) Post-exposure & $1: 16$ & Negative \\
(10) Post-exposure & $>1: 16$ & Negative \\
(11) Post-exposure & & \\
(Infants) & Negative & Negative \\
(12) No exposure & Negative & Negative \\
(13) No exposure & &
\end{tabular}

this fraction was found to give an optimum specific reaction and a minimum of nonspecific background stain. The source of antigen consisted of coverslip cultures of continuous line monkey kidney cells (LLC-MK2) which were chronically infected with rubella virus. This rubella associated. line (RA) has been subcultured for 25 generations over a 2 -year period and possesses certain biological and morphological features which differentiate it from an uninfected line of the same cells. The persistence and growth curve of rubella virus in these cells has been described (7). The time for removal of coverslip cultures was found to be critical. Cultures

\footnotetext{
* Baltimore Biological Laboratory.
} 
removed during the first 3 days were found to be unsatisfactory because of background, nonspecific staining as were older cultures removed between the 8 th and 12 th day after seeding. The optimum period between the 4th and the 7th day resulted in uniform monolayers of better staining

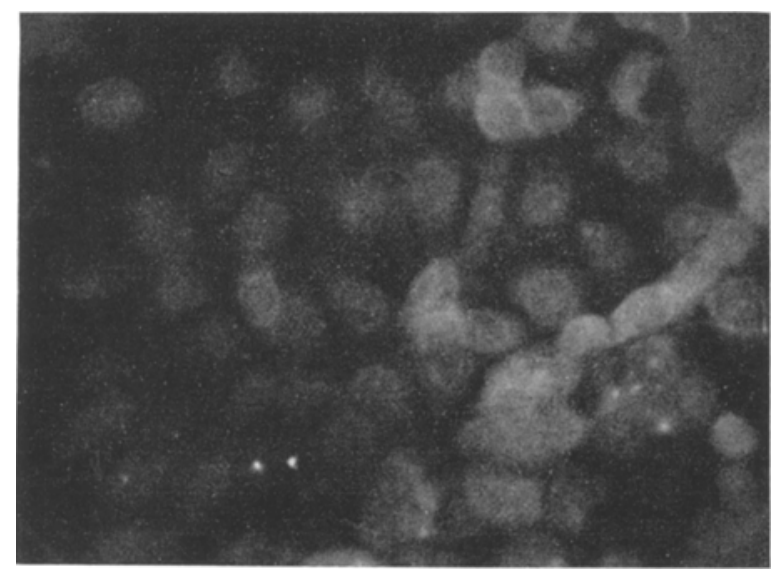

Fìg. 1. Normal cells stained with fluorescein-labelled anti-human gamma globulin serum by indirect technique following $1 / 4$ dilution of human rubella convalescent serum (X 250).

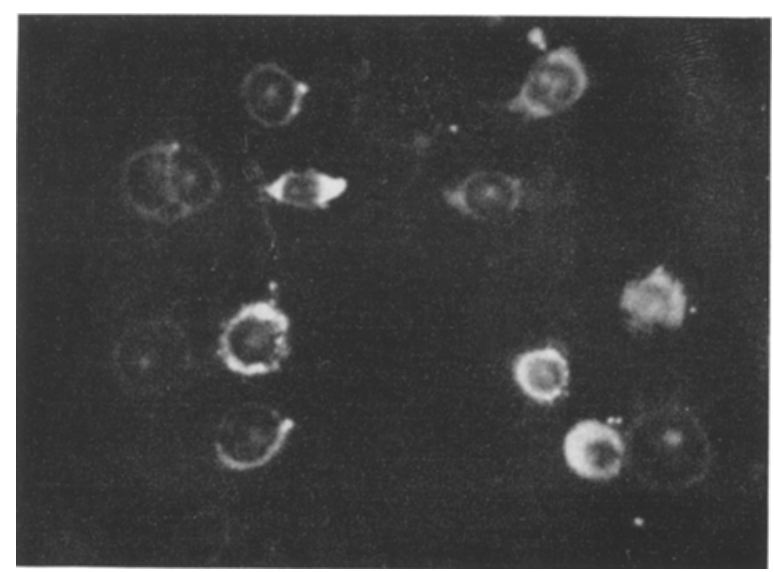

Fig. 2, Rubella assoeiated (RA) cells stained with fluoregcein-labelled snti-human gamma giobuili serum by indirect technique following $1 / 4$ dilution of human vubelia convalescent serum (X 250).

cells. This period also corresponded exactly with that of maximum virus production (7). Chronically infected and normal coverslip cultures were washed in phosphate buffered saline at $\mathrm{pH}=7.3$, fixed in acetone for 20 minutes with a change of fresh acetone after 10 minutes and air dried for a minimum of 30 minutes. One or two drops of appropriate dilutions 
of the human serum were then added to the coverslips. After incubation for one hour at $37^{\circ} \mathrm{C}$ the coverslips were washed three times for $10 \mathrm{mi}$ nutes each in phosphate buffered saline, then stained for one hour at $37^{\circ} \mathrm{C}$ with fluorescein-labelled goat antihuman gamma globulin. The coverslips were again washed three times for 10 minutes each, mounted on glass slides and examined under a binocular microscope with a darkfield condenser using an Osram HBO-200 light source. The filter system included a UG-5 exciter and an OG-4 and OG-5 barrier filter combination. The reactions were graded according to the brilliance of fluorescence and titration endpoints were taken as the highest serum dilution giving a $3+$ or $4+$ stain.

Table 1 presents the fluorescent antibody titers obtained with pairs of acute and convalescent serum, and with convalescent sera from other cases of clinically diagnosed rubella from 3 of which virus had been recovered. In all instances, specific reactions were recorded on infected cells with convalescent sera obtained approximately one month after onset. In contrast, acute specimens taken within 48 hours of rash were negative except for one which had a very low titer. A serum dilution of at least 1:8 was found to be best for differentiation of reaction. Both acute and convalescent specimens were completely negative with normal, uninfected cells. Figs. 1 and 2 illustrate the reaction of a convalescent serum with normal and with infected cells. It will be noted that the specific stain is intracytoplasmic. Serum was also obtained from four additional women, including two who were pregnant, 4 to 6 weeks after known exposure to cases of rubella. These specimens were all positive, possibly as a result of subclinical infection. Two sera from 7 month old infants were completely negative. Additional studies are being made (8).

\footnotetext{
Abstract

Antibodies for rubella virus were detected in human serum and titrated by the indirect method of immunofluorescence using a chronically infected, continuous line of monkey kidney cells as antigen. Positive reactions were obtained with convalescent or post-exposure specimens while acute sera and those from unexposed individuals were negative.

The authors wish to acknowledge the technical assistance of Mrs. Margaret Jakobovits.

References

1. Parkman, P. D., E. Buescher, and M. S. Artenstein: Proc. Soc. Exp. Biol. and Med. 111, 225 (1962).

2. Weller, T. H., and F. A. Neva: Proc. Soc. Exp. Biol. and Med. 111, 215 (1962).

3. Sigurdardottir, B., K. F. Givan, K. R. Rozee, and A. J. Rhodes: Canad. Med. Ass. J. 88, 128 (1963).
} 
Detection of Rubella Antibodies by the Indirect Fluorescent Technique 463

4. Riggs, J. L., and G. C. Brown: Proc. Soc. Exp. Biol. and Med. 110, 833 (1962).

5. Brown, G. C.: unpublished data.

6. Riggs, J. L., P. O. Loh, and W. C. Eveland: Proc. Soc. Exp. Biol. and Med. 105, 655 (1960).

7. Maassab, H. F., J. A. Veronelli, and A. V. Hennessy: Abstract, Amer. Soc. Microbiol. 64th Annual Meeting, Bact. Proc. p. 144 (1964). 